\title{
Membangun Keunggulan Bersaing Melalui Strategi Umbrella Brand
}

\author{
Saren Prit dan Mumuh Mulyana \\ Program Studi Manajemen, Institut Bisnis dan Informatika Kesatuan \\ Bogor, Indonesia \\ E-Mail: mumuh.mulyana@ibik.ac.id
}

\begin{abstract}
Business and consumer behavior that is always changing and growing rapidly requires companies to make changes in strategy to increase competitive advantage. The purpose of this study is (1) To determine the strategy of internal and external factors in implementing umbrella brand strategy at PT. Indofood as a competitive advantage. (2) To find out the strategy applied in developing the umbrella brand strategy of PT. Indofood Sukses Makmur as a competitive advantage. The results of this study are (1) Brand that has long been known by the people of Indonesia gets a weight of 0.104 and a rating of 3.8, Brand Image known as a food solution weighs 0.066 and a rating of 3.8, a Brand that has a sufficiently mature strategy is included in the Umbrella brand strategy and excels in competing . (2) PT Indofood's main strengths are brands that have a mature enough strategy, including umbrella brand strategy and excel in competition, Indofood's main weakness is Umbrella Brand (umbrella of many products) which creates confusion among consumers' perceptions of the products number, Indofood's main opportunity is Relationship with stakeholders (communities, retail traders), Indofood's Main Threats are several types of products that have similarities with competitors. (3) Indofood which is in quadrant I position that implements an aggressive strategy using internal strength to take advantage of external opportunities.
\end{abstract}

Keywords : umbrella brand, competitive advantage.

\section{PENDAHULUAN}

Umbrella brand adalah nama merek yang sama mendukung berbagai produk di pasar berbeda, dimana masing-masing produk memiliki komunikasi dan janji individual sendirisendiri. Praktik pemasaran ini berbeda dari perluasan merek dalam umbrella brand tersebut melibatkan pemasaran produk sejenis, bukan produk yang berbeda, dengan satu merek. Oleh karena itu, umbrella brand dapat dianggap sebagai jenis perluasan merek. Praktik branding tidak melarang perusahaan menerapkan pendekatan branding yang berbeda untuk lini produk yang berbeda (misalnya perluasan merek).

Salah satu contoh kasus yang dapat diamati adalah pada PT Indofood yang menggunakan strategi brand yaitu PT Indofood yang memiliki lebih dari 10 lini produk yang fokus pada produk makanan/ food solution.Strategi merek ini digunakan Indofood agar unggul dalam bersaing. Bagaimana Indofood menggunakan strategi umbrella brand untuk semua produknya seimbang baik dalam promosi sebagai salah satu contoh dapat dilihat Indofood selalu fokus dalam produk mie instan dalam promosinya dan tidak banyak konsumen yang mengetahui mengenai produk. Indofood.

Indofood sudah cukup lama terjun ke market place Indonesia dalam kategori makanan atau bahan pelengkap untuk makanan. Indofood adalah salah satu brand yang berada di bawah umbrella brand. Indofood memiliki market share yang cukup tinggi di pasar Internasional. Berdasarkan data web Indofood Pada Pebruari tahun 2017, Indofood memiliki 7,85\% market share global dengan angka penjualan $\mathrm{Rp} 35.65$ trilliun dari $\mathrm{Rp} 34.08$ trilliun. Sedangkan berdasarkan data katadata.co.idmarket share domestik yang diraih untuk mie instan Indofood adalah $70,7 \%$. Sebagai sebuah brand yang sudah sangat mapan di

JIMKES

Jurnal Ilmiah Manajemen Kesatuan Vol. 7 No. 3, 2019 pp. 303-312
IBI Kesatuan ISSN $2337-7860$ 
Umbrella Brand Strategy

$\underline{304}$ pasar internasional, Indofood memiliki beberapa masalah yang cukup krusial. Salah satunya adalah bagaimana strategi umbrella brand dapat berhasil dalam unggul bersaing namun tidak pula lepas dari hambatan. Semuanya akan di pengaruhi faktor internal dan eksternal. Dan dalam strategi umbrella brand dari Indofood masing-masing productnya memilki strategi sendirinya untuk menguasai pasar terutama

Penelitian Ini bertujuan untuk: (1) Untuk mengetahui strategi faktor internal dan faktor eksternal dalam penerapan strategi umbrella brand pada PT. Indofood sebagai keunggulan bersaing. (2) Untuk mengetahui strategi yang diterapkan dalam pengembangan strategi umbrella brand PT.indofood sebagai keunggulan bersaing.

\section{TINJAUAN PUSTAKA \\ Umbrella Brand}

Menurut Tjiptono (2011:29) yaitu nama merek yang sama mendukung berbagai produk dipasar berbeda, di mana masing-masing produk memiliki komunikasi dan janji individual sendiri-sendiri. Menurut Keller (2014) konsep umbrella brand adalah pratik pemasaran yang melibatkan penjualan banyak produk terkait dengan satu merek. Oleh karena itu, melibatkan penciptaan ekuitas merek yang besar untuk satu merek. Dalam prakteknya, menerapkan umbrella branding dapat menantang pemasaran bagi pemasar karena ia perlu berkoordinasi secara efektif di antara semua merek individual. Namun kenyataannya, ini bisa menjadi keuntungan yang menakjubkan juga.Ide dasar di balik strategi ini adalah untuk meningkatkan daya jual produk dan mengikuti konsep psikologis bahwa produk yang menghasilkan nama merek yang sama diproduksi dengan menggunakan standar kualitas tinggi yang sama. Jadi, sebuah merek mungkin memiliki 10 lini produk, namun kepercayaan pada merek itu, memanfaatkan atribut dari semua 10 lini produk.

Faktor-faktor yang dapat menentukan dampak dari umbrella branding meliputi:

1. Tingkat kesamaan antara produk yang jatuh di bawah perusahaan yang terkait umbrella brand (misalnya apakah produk dapat bertindak sebagai satu sama lain.

2. Ekuitas merek dari perusahaan (misalnya apakah merek tersebut Dikenal produknya di pasar.

\section{Keunggulan Bersaing (Competitive Advantange)}

Dalam Karyanya yang paling terkenal Competitive Strategy (terjemahan), Michael E. Porter (2008:13) mengungkapkan beberapa strategi yang dapat digunakan perusahaan agar dapat bersaing. Beberapa aspek inti teori porter itu adalah: (1) Persaingan Merupakan inti keberhasilan dan kegagalan. Inti berarti suatu keberhasilan dan kegagalan bergantung pada keberanian perusahaan untuk bersaing. Tanpa berani bersaing, tidak mungkin keberhasilan diperoleh. Strategi bersaing bertujuan untuk mempertahankan tingkat keuntungan dan posisi yang langgeng ketika menghadapi persaingan, (2) Keunggulan bersaing. Berkembang dari nilai yang mampu diciptakan oleh perusahaan bagiPelanggan atau pembeli. Keunggulan bersaing menggambarkan cara perusahaan memilih dan mengimplementasikan strategi generik (biaya rendah, deferensiasi, dan fokus) untuk mencapai dan mempertahankan keunggulan bersaing. Dengan perkataan lain, keunggulan bersaing menyangkut cara suatu perusahaan menerapkan strategi generiknya dalam kegaiatan praktis., (3) Dua jenis dasar keunggulan bersaing yaitu biaya rendah (low cost) dan deferensiasi. Keunggulan semua itu berasal dari struktur industri. Perusahaan yang berasal dengan strategi biaya rendah yaitu : memiliki kemampuan dalam mendesain produk, dan pasar yang lebih efesien dibandingkan pesaing. Perusahaan yang berasal dengan deferensiasi (deferentiation) yaitu : kemampuan untuk menghasilkan barang dan jasa yang unik dan memiliki nilai lebih (superior value) bagi pembeli dalam bentuk kualitas produk, sifat sifat khusus, dan pelayanan lainnya. (4) Strategi biaya rendah (Low Cost Strategy). Strategi ini mengandalkan keunggulan biaya yang relatif rendah dalam menghasilkan barang dan jasa. Keunggulan biaya berasal dari: Pengerjaan berskala ekonomis, Teknologi milik sendiri dan Kemudahan akses untuk mendapatkan bahan baku. (5) Diferensiasi (Differentiation). Keunggulan fokus diferensiasi berasal dari kemampuan perusahaan untuk menghasilkan barang dan jasa yang unik dalam industrinya dan dalam 
semua dimensi secara umum dihargai pembeli. Diferensiasi dapat dilakukan dalam beberapa bentuk, antara lain: Diferensiasi produk, Diferensiasi sistem penyerahan atau penyampaian produk, Diferensiasi dalam pendekatan pemasaran, Diferensiasi dalam peralatan dan konstruksi, Diferensiasi dalam citra produk. Dengan keunggulan bersaing, menurut Porter, perusahaan dapat memiliki kinerja di atas rata-rata industri lain. Keunggulan bersaing merupakan kinerja perusahaan yang dapat tampil di atas rata-rata. (6) Strategi Fokus (Focus Strategy). Strategi Fokus berusaha mencari keunggulan dalam segmen sasaran pasar tertentu meskipun tidak memiliki keunggulan bersaing secara keseluruhan. Ada dua fokus, yaitu : (a) Fokus biaya yaitu dilakukan perusahaan dengan cara mengusahakan keunggulan biaya dalam segmen sasarannya. Dan (b) Fokus diferensiasi yaitu dilakukan perusahaan dengan cara mengusahakan diferensiasi dalam segmen sasarannya. Sasaran dalam hal ini adalah pembeli dengan pelayanan yang paling baik dan berbeda. Dengan yang lainnya.

Elemen-elemen dari keunggulan bersaing (competitive advantange): Harga, Pengaruh/ Efek Pengalaman, Pangsa Pasar, Hambatan untuk memasuki pasar, Nama merek/ Brand, Distribusi, Diferensiasi, Kualitas Produk dan Kepuasan Pelanggan.

\section{METODOLOGI PENELITIAN}

Metode Penelitian merupakan cara dalam usaha memahami objek penelitian bertujuan untuk memadu penelitian tentang urutan-urutan bagaimana penelitian dilakukan guna menemukan, mengembangkan dan menuju kebenaran suatu pengetahuan. Dalam Penyusunan penelitian ini, metode penelitian yang digunakan deskriptif. Metode deskriptif adalah metode yang memberikan gambaran atau uruaian atas suatu keadaan sejelas mungkin tanpa ada perlakuan terhadap objek yang diteliti (Kountur 2005,105). Ciri-ciri dari penelitian deskriptif adalah :

1. Berhubungan dengan keadaan yang terjadi saat itu.

2. Menguraikan satu variabel saja atau beberapa variabel namun Diuraikan satu persatu

3. Variabel yang diteliti tidak dimanipulasi atau tidak ada perlakuan. Pelaksana metodemetode desriptif tidak terbatas hanya sampai pada pengumpulan dan penyusunan data, tetapi meliputi analisa dan interpretasi tentang arti data itu.

Sumber Data : (a) Data Primer; Data yang diperoleh secara langsung dari narasumber (para pakar) dengan tidak melalui perantara. Data primer merupakan opini subjek secara individual maupun kelompok. Hasil observasi terhadap suatu benda, kejadian atau kegiatan, hasil pengujian. Data Primer peneliti ini antara lain : Data factor internal dan factor eksternal permasalahan terkait pengembangan strategi Umbrella brand. (b) Data Sekunder, data sekunder merupakan sumber data penelitian yang diperoleh peneliti secara tidak langsung melalui media perantara. Data sekunder umumnya berupa bukti, catatan atau laporan historis yang telah tersusun dalam arsip yang dipublikasikan dan yang tidak dipublikasikan.

Metode analisis yang digunakan dalam penelitian ini adalah bertujuan untuk mendeskripsikan strategi pengembangan produk. Metode analisis yang digunakan terdiri dari analisis deskriptif dan analisis formulasi-formulasi strategi. Adapun alat bantu analisisi yang digunakan merumuskan strategi pemimpin pasar dan penantang pasar adalah matriks EFE, matriks IFE, matriks IE, matriks SWOT , matriks SPACE dan matriks QSPM

\section{HASIL DAN PEMBAHASAN}

Berdasarkan hasil pengisian kuisoner yang telah diisi oleh 5 pakar yaitu Digital Marketing Manager IDMarco, Marketing Communication Manager IDMarco, Marketing Consultant, Sales \& Supply Consultant, Dosen Pemasaran STIEK. Hasil kuesioner yang telah diisi oleh pakar dianalisis menggunakan matriks yaitu matriks EFE,IFE, IE, SWOT, SPACE dan QSPM.

\section{Matriks EFE (External Factor Evaluation)}

Faktor-faktor yang dianalisis dengan matrik ini adalah faktor strategis dari Indofood. Faktor- faktor strategis yang dianalisis adalah peluang dan ancaman bagi indofood di masa yang akan datang. 
Umbrella Brand

Strategy

$\underline{306}$

\section{Peluang (OPPORTUNITIES)}

a. Faktor Pertumbuhan Pasar yang terus meningkat baik dikalangan bawah,menengah maupun atas mendapatkan bobot 0,10 dan rating untuk faktor ini adalah 2,2. Faktor ini mendapatkan peringkat kelima dari lima poin peluang yang di analisis. Hal ini menunjukan bahwa Indofood mempunyai kemapuan yang cukup baik dalam meraih peluang ini. Dengan melakukan promosi/memperkenalkan semua produkproduknya melalui internet seiring dengan pertumbuhan pasar yang terus meningkat

b. Faktor Melalukan Memanfaatkan e-bussines dalam membantu pangsa pasar dan memperkenalkan produk melalui internet karena pengguna internet sama dengan masyarakat konsumen.bobot 0,108 dan rating untuk faktor ini adalah 3 . Faktor ini mendaptkan peringkat kedua dari lima poin peluang yang dianalisis. Faktor ini adalah peluang utama dalam peluang indofood. Hal ini menunjukan bahwa indofood mempunyai kemampuan yang baik dalam meraih peluang ini. Yaitu Indofood memanfaatkan internet menjadi salah satu yang membantu penjualan atau pangsa pasar untuk Indofood yang dilakukan oleh distributor penjualan Indofood yaitu IDMarco yang memiliki tanggung jawab akan penjualan semua produk Indofood salah satunya melalui internet.

c. Faktor hubungan dengan stakeholder (masyrakat sekitar, pedagang/toko eceran, mendapatkan bobot 0,116 dan rating untuk faktor ini adalah 3 . Faktor ini mendapatkan peringkat pertama dari lima poin peluang yang dianalisis. Hal ini menunjukan bahwa Indofood mempunyai peluang yang baik dalam meraih peluang ini. Dengan melakukan atau membina hubungan yang baik dan berjalan baik dengan masyarakat dan pedangan/ toko eceran dapat mempermudah atau membantu penjualan pada indofood dan adanya keuntungan untuk indofood pendistribusian juga lebih mudah.

d. Faktor kemampuan daya beli konsumen untuk semua produk mendapatkan bobot 0,108 dan rating untuk faktor ini adalah 3,2. Faktor ini merupakan peluang kedua dalam peluang indofood. Hal ini menunjukan bahwa indofood mempunyai peluang baik dalam meraih peluang ini. Pola masyarakat akan kebutuhan pelengkap makan, bumbu makanan atau mie instan, susu instan, dan lain sebagainnya cukup tinggi. Pada era seperti ini masyrakat atau konsumen lebih suka pada segala yang instan atau mempermudah, simpel, harga terjangkau dan pada citra rasa yang sesuai dan pas. Contohnya bumbu-bumbu instan yang banyak di ciptakan oleh indofood yang mempermudah ibu-ibu dalam memasak karena tidak perlu meracik bumbu.

e. Faktor Peluang pasar yang besar dalam sistem distribusi yang mencakup grup pendistribusian produk hingga pasar tradisional dengan waktu yang sesingkat mungkin mendapatkan bobot 0.104 dan rating untuk faktor ini adalah 3,2. Faktor ini merupakan peluang tepenting karena dengan usaha distribusi konsumen akan mengetahui produk indofood dan karena konsumen sudah mengetahui lewat distribusi yang luas akan muncul niat beli dan sesuai kebutuhan konsumen dan distribusi ke pasar tradisional dapat mempengaruhi konsumen baik secara langsug atau tidak langsung. Banyaknya produk-produk indofood yang dapat membuat konsumen maka itu distribusi sangat penting agar konsumen mengetahui semua produk indofood secara merata.

\section{Ancaman ( THREATS)}

a. Faktor Beberapa produk/ jenis produk memiliki kesamaan dengan pesaing mendapatkan bobot 0,104 dan rating untuk faktor ini adalah 2,4. Faktor ini menunjukan bahwa ancaman memberikan pengaruh yang kuat sebagai ancaman kedua. Setiap bisnis atau perusahaan memiliki pesaing/ adanya persaingan baik dari segi produk, Harga, promosi atau yang lainnya. Persaingan yang positif akan membawa perbaikan kualitas serta akan unggul dalam bersaing dan fokus pada perbaikan kualiatas produk.

b. Faktor Selera Konsumen yang selalu berubah mendapatkan bobot 0,08 dan rating untuk faktor ini adalah 2,4. Faktor ini merupakan ancaman utama pada indofood karena indofood harus memantau, mengetahui, mengikuti apa yang sedang di 
inginkan oleh konsumen. Hal ini menunjukan bahwa ancaman memberikan pengaruh yang sangat kuat sebagai ancaman utama. Perusaahaan harus mengetahui keinginan konsumen secara cepat yang selalu ingin sesuatu yang baru atau keunikan dari rasa yang belum ada atau belum diciptakan oleh perusahaan lain.

c. Faktor pertumbuhan ekonomi yang fluktuasi dan pertumbuhan pasar dalam negeri dan luar negeri faktor ini mendapatkan bobot 0,1 dan rating untuk faktor ini adalah 2,2. Faktor ini merupakan ancaman kedua pada indofood yang mempengaruhi dalam tingkat penjualan jika pertumbuhan ekonomi sedang menurun maka akan mengakibatkan berkurangnya penjualan, jika pertumbuhan ekonomi sedamh naik dan sedang akan berpengaruhi pada peningkatan penjualan yang lebih baik.

d. Faktor kebijakan pemerintah dalam perdagangan international (ekspor-Impor, PPn, Perijinan) faktor ini mendapatkan bobot 0,076 dan rating untuk faktor ini adalah 2,2. Faktor ini merupakan faktor selanjutnya yang harus diperhatikan karena berpengaruh juga dalam tingkat penjualan yaitu seperti kebutuhan bahan baku yang di butuhkan indofood, mengekspor productnya akan melawati peraturan/ kebijakan pemerintah seperti PPn, dan ada perijinan, dan ada juga tes uji kesehatan untuk semua produk indofood agar mengetahui layak atau tidaknya dikonsumsi itu sangat menjadi ancaman karena akan menambah biaya.

e. Faktor Persaingan harga dengan kompetitor faktor ini mendapatkan bobot 0,104 dan rating untuk faktor ini adalah 2,2. Faktor ini merupakan faktor ancaman yang sangat kuat. Harga merupakan hal yang penting dalam sebuah produk termasuk dalam indofood menutupi segala biaya atau tidak/ menjadi keuntungan yang sangat besar tetapi jangan kemahalan untuk konsumen dan juga saingan indofood yang mempunyai harga yang terjangkau murah dan kualitas menyerupai itu adalah suatu ancaman yang paling kuat. Karena semua konsumen mencari harga yang realtif murah dengan kualitas produk yang baik dan sesuai keinginan. Jadi Indofood harus mempunyai suatu strategi harga agar tetap menjadi kebutuhan untuk konsumen dan memaksimalkan tingkat penjualan pada indofood.

\section{Matriks IFE (Internal Factor Evaluation)}

Faktor-faktor yang dianalisis dengan matrik ini adalah faktor-faktor strategis internal indofood. Faktor-faktor strategis yang dianalisis adalah kekuatan dan kelemahan bagi indofood di masa yang akan datang.

\section{Kekuatan (Strengths)}

a. Faktor Brand yang telah lama dikenal oleh masyakarat indonesia mendapatkan bobot 0,104 dan rating untuk faktor ini adalah 3,8. Faktor ini mendapatkan peringkat ke dua dari tujuh poin kekuatan yang dianalisis. Indofood berhasil membuat bradn telah dikenal bahkan di benak masyakarat Indonesia yang telah lama dan bertahan sampai sekarang ini dengan segala strategi yang digunakan oleh indofood agar mempertahankan brand nya yang produknya banyak digemari atau disuka oleh konsumen. Kekuatan ini sangat tinggi dalam sebuah perusahaan karena sebuah brand adalah sebuah identitas dari produk atau perusahaan.

b. Faktor Citra Merek dikenal sebagai food solution mendapatkan bobot 0,066 dan rating untuk faktor ini adalah 3,8. Faktor ini mendapatkan peringkat ke enam dari tujuh poin kekuatan tetapi yang kuat dalam faktor kekuatan karena sudah diketahui Indofood yang berjalan di bidang makan, pelengkap bahan makanan, bumbu, susu, makanan yang instan maka dari itu memiliki nama tersendiri di benak konsumen sebagai food solution sebagai contoh produknya adalah pop mie dan indomie yang instan dan mudah untuk di konsumsi atau diolah, dan untuk susu indomilknya yang mempermudah juga dan lain sebagainnya dan konsumen merasa terbantu dengan adanya indofood sebagai food solution ini

c. Faktor kualitas produk yang baik dan stabil mendapatkan bobot 0,09 dan rating untuk faktor ini adalah 3,6. Faktor ini mendapatkan peringkat ke empat dari tujuh poin kekuatan yang dianalisis. Indofood berhasil menciptakan kualitas produk yang baik dan mengembangkan produk yang stabil dengan segala usaha 
Umbrella Brand

Strategy

308 mempertahankanya. Kualitas yang baik yang telah diciptakan membuat konsumen percaya akan produk-produk yang diciptakan indofood.

d. Faktor Mendapatkan banyak penghargaan mendapatkan bobot 0,066 dan rating untuk faktor ini adalah 3,2. Faktor ini mendapatkan peringkat ke tujuh dari tujuh poin/ peringkat terakhir dalam kekuatan yang dianalisis. Kekuatan Indofood mendapatkan berbagai perhargaan merupakan Faktor yang cukup penting bagi kekuatan Indofood. Hal ini akan berpengaruh terhadap tanggapan positif konsumen kepada. Maka hal ini membutikan bahwa perusahaan Indofood adalah perusahaan yang berprestasi baik tingkat nasional maupun international dan membuat konsumen semakin percaya akan kualitas produk-produk Indofood.

e. Faktor Pendistribusian yang luas untuk semua produk mendapatkan bobot 0,1 dan rating untuk faktor ini adalah 3,8. Faktor ini mendapatkan peringkat ke tiga dari tujuh poin kekuatan yang dianalisis. Faktor ini merupakan kekuatan yang utama dalam Indofood agar dapat meraih pangsa pasar yang luas atau perluasan Brand. Kekuatan Indofood pada pendistribusian yang luas merupakan faktor yang paling penting bagi kekuatan Indofood. Dengan adanya faktor pendistribusia yang luas maka hal ini akan mempermudah konsumen mendapatkan produk Indofood dan menjangkau pelanggan dengan luas.

f. Faktor Strategi brand loyalty dalam pengaplikasian CSR bagi konsumen mendapatkan bobot 0,07 dan 3,4. Faktor ini mendapatkan peringkat ke lima dari tujuh poin kekuatan yang dianalisis. Faktor ini merupakam kekuatan tambahan bagi Indofood yang penting karena dengan progam CSR membuat konsumen lebih mengenal Indofood dengan baik tidak hanya dari bisnis/ penjualan produk indofood tetapi dari segi yang sudah di aplikasikan oleh CSR dan mengerti konsumen, lingkungan dan lain-lain. Dan pengaplikasiaan CSR ini adalah salah satu bentuk strategi brand loyalty.

g. Faktor Brand yang memiliki strategi yang cukup matang termasuk dalam strategi Umbrella Brand dan unggul dalam bersaing mendapatkan bobot 0,12 dan mendapatkan rating 3,6. Faktor ini mendapatkan peringkat ke satu dari tujuh poin kekuatan yang dianalisis. Faktor kekuatan ini meruapakan faktor yang sangat penting karena strategi brand sangat penting dalam segala segi penjualan indofood agar semua produk yang telah diciptakan indofood sesuai dan banyak konsumen yang mengetahuinya dan unggul dalam bersaing dan stategi Umbrella Brand pada Indofood karena agar konsumen dalam segala makanan atau pelengkap bumbu masakan, minuman, snack mengkonsumsi semua merek indofood dan indofood karena strategi brand ini di kenal sebagai food solution tidak hanya nasional tetapi international juga karena indofood sudah matang dalam memayungi beberapa produk yang ada dalam brand Indofood.

\section{Kelemahan (Weaknesses)}

a. Faktor Umbrella Brand (Memayungi banyak produk) yang menciptakan dampak kebingungan persepsi konsumen akan banyaknya produk mendapatkan bobot 0,164 dan mendapatkan rating untuk faktor ini adalah 2,4. Faktor ini mendapatkan peringkat ke satu dari 3 point kelemahan yang dianalisis. Faktor ini merupakan faktor yang utama dalam kelemahan karena karena banyaknya produk indofood yang berbeda-beda membuat konsumen bingung dan beberapa produk tidak di ketahui bahwa dari indofood contohnya kecap piring dan maggi banyak konsumen yang tidak mengetahui bahwa salah satunya 2 produk itu adalah produk dari brand indofood yang memayungi 2 produk tersebut.

b. Faktor beberapa produk memiliki packaging yang serupa/mirip dengan produk pesaing mendapatkan bobot 0,124 dan mendapatkan rating untuk faktor ini adalah 2,2. Faktor ini mendapatkan peringkat ke dua dari tiga point kelemahan yang dianalisis. Faktor ini merupaka kelemahan dari indofood yang kuat karena membuat konsumen tejebak contohnya dalam produk indofood, indomie, saos dan lainnya yang memiliki kemasan serupa dengan pesaing dan konsumen akan terjebak dalam pembelian karena hanya memperhatikan kemasannya saja. Namun 
indofood harus mempunyai strategi yang kuat dalam kemasan inovasi yang baru dan terus update untuk mengatasi faktor kelemahan tersebut.

c. Faktor Beberapa produk yang kurang memiliki promosi yang kuat mendapatkan

bobot 0,14 dan mendapatkan rating untuk faktor ini adalah 2,4. Faktor ini mendapatkan peringkat ke tiga dari tiga point kelemahan yang dianalisis. Faktor ini yang penting dalam kelemahan karena berkaitan atau berpengaruh pada penjualan karena beberapa produk indofood kurangnya promosi dan beberapa konsumen tidak mengetahuinya dan memilih merek pesaing karena kurang mengenal produk indofod. Contohnya pada produk indofood yaitu terigu taj mahal yang kurang promosi karena indofood terlalu fokus pada terigu yaitu promosi bogasari/ cakra kembar saja. Maka dari itu Indofood harus gencar dalam melakukan promosi secara merata.

\section{Matriks IE}

Berdasarkan hasil analisis internal diperoleh skor tertimbang 3,2336 sedangkan dari hasil analisis eksternal diperoleh skor tertimbang 2,628. Maka gabungan dari faktor internal dan eksternal (tabel IFE dan EFE) tersebut memperlihatkan posisi objek yang sedang diteliti yaitu Indofood berada pada ruang IV yaitu Strategi tumbuh dan bina (Growth and Build) pertumbuhan. Selanjutnya hasil tersebut pada Indofood dapat melakukan kegiatan penetrasi pasar dan langkah penyempurnaan strategi pengembangan produk Indofood untuk mempertahankan dan memelihara kinerja yang sudah dicapai. Peningkatan dalam kreatifitas varian produk yang dihasilkan Indofood menjadi sangat diperlukan sehingga menghasilkan produk yang sesuai kebutuhan konsumen dan juga terkait bagaimana strategi promosi yang harus dilakukan untuk beberapa produk Indofood agar konsumen mengetahui keberadaan produk yang telah diciptakan Indofood.

Maka dengan hal ini dapat meminimalisasi ancaman pada faktor selera konsumen yang selalu berubah-ubah dan persaingan yang semakin ketat. Kaenakaragaman dalam varian produk dan strategi-strategi lainnya perlu dilakukan demi meningkatkan keunggulan dalam bersaing.

\section{Matriks SWOT}

\section{Strategi SO}

Faktor kekuatan merupakan faktor internal atau faktor yang berasal dari dalam perusahaan (bisnis) yang mampu mendukung perkembangan bisnis secara optimal jika potensi yang ada atau dimiliki dimaksimalkan. Strategi SO Indofood adalah :

a. Mempertahankan Pasar yang telah ada dan mengembangkan pangsa pasar. Dengan pasar yang telah ada indofood hanya mempertahankan /mengembangkan pasar agar lebih luas dan mampu dalam bersaing dalam proses pengembangan pasar agar tidak adanya pesaing yaitu dengan cara terus inovasi-inovasi terbaru dari produk dan mengembangkan pasar secara luas baik nasional maupun international

b. Meningkatkan strategi brand dengan berbagai cara promosi dengan cara semua produk yang telah di ciptakan oleh indofood di promosikan dengan berbagai cara promosi baik melalui media, event dan lain sebagainya.

c. Mengembangkan citra merek agar merek dapat selalu di ingat oleh konsumen brand indofoofd sudah terkenal di kalangan konsumen sebagai food solution. Indofood menyediakan/ menciptakan segala pelengkap, bumbu masakan, snack yang telah memiliki citra merek di benak konsumen dan indofood harus mampu untuk menyediakan segala kebutuhan konsumen dengan update dan mengikuti perkembangan yang ada.

d. Dengan adanya daya beli masyarakat, maka lebih mempermudah pendistribusian produk. Dengan daya beli yang semakin meningkat maka perusahaan akan lebih memperluas pendistribusian guna meningkatkan permintaan pada produk-produk indofood dan mencegah masuknya pesaing dan unggul dalam bersaing

\section{Strategi $W O$}

Strategi WO bertujuan untuk memperbaiki kelemahan dengan memanfaatkan peluang eksternal. Strategi WO Indofood adalah : 
Umbrella Brand Strategy

$\underline{310}$ a. Meningkatkan diversifikasi produk-produk baru adalah usaha indofood guna mempertahankan konsumen dengan berbagai cara salah satunya adalah melakukan diversifikasi produk dan menghindari masuknya saingan dan sesuatu yang terbaru/ versi baru dari produk yang berbeda dari pesaing dan memenuhi kebutuhan konsumen/ pasar

b. Aktif dalam internet demi memperkuat daya beli konsumen dan selalu ingat terhadap produk atau merek di era globalisasi ini perusahaan indofood harus mampu melakukan segala promosi atau kegiatan melalui internet salah satunya seperti bentuk-bentuk produk terbaru dari Indofood berjualan secara online yaitu salah satunya dalam indofood yang melakukan kegiatan online yaitu anak perusahaan yaitu IDMarco yang melalukan kegiatan/ aktif di internet melakukan pejualan/ penawaran, promosi melalui internet. Aktif di internet guna menambah penjualan atau penjualan dijangkau luas.

c. Melakukan Promosi yang seimbang terhadap produk-produk yang ada. Indofood harus seimbang dalam melakukan promosi. Sebagai contoh promosi produk indofood yang gencar adalah indomie sedangkan yang kurang promosi di Indofood adalah seperti terigu Tajmahal, Kecap piring lombok. Guna keseimbangan dalam penjualan antar semua produk-produk Indofood

d. Lebih mengutamakan kualitas produk. Indofood menggunakan bahan baku makanan yang berkualitas yang diperoleh dari perkebunan yang sudah memenuhi standar (good coming pratice) hal ini yang membuat kualitas dari Indofood baik

\section{Strategi ST}

Strategi ST menggunakan kekuatan perusahaan untuk menghindari atau mengurangi dampak ancaman eksternal. Strategi ST Indofood adalah :

a. Mempunyai strategi yang tepat dalam menghadapi pesaing. Indofood memiliki strategi untuk menghadapi pesaing salah satunya adalah strategi umbrella brand demi keunggulan dalam bersaing, dan banyak lagi strategi yang telah di terapkan baik dari segi internal atau eksternal dan harus sesuai dengan rencana perusahaan

b. Memiliki citra merek yang baik untuk menghadapi pesaing. Indofood telah memiliki citra merek yang baik di mata konsumen untuk menghadapi pesaing karena indofood telah menjadi food solution yang lengkap dan di butuhkan oleh konsumen

c. Mengikuti Selera konsumen perusahaan harus tanggap dalam mengetahui dan mengikuti apa keinginan/ selera dari konsumen agar konsumen tidak tertarik pada produk lain/ merek lain. Selain selera harus mengetahui bagaimana perilaku konsumen dalam keinginan membeli produk. Dengan mengikuti selera konsumen perushaan harus melakukan inovasi produk.

Strategi $W T$

Strategi ST adalah strategi defensive untuk mengurangi kelemahan internal dan menghindari ancaman. Strategi WT Indofood adalah:

a. Meningkatkan inovasi-inovasi terbaru untuk produk demi meningkatkan cara citra merek dan bersaing dengan pesaing agar perusahaan tidak dibawah pesaing

b. Mencari tahu informasi pergerakan pesaing baik pemasaran, periklanan. Agar Indofood tetap bertahan dan selalu menjadi pemimpin pasar.

\section{Matriks SPACE}

Matriks SPACE merupakan kerangka 4 kuadran yang mengindikasikan apakah strategi yang agresif, konservatif, defensive, atau kompetitif yang paling sesuai untuk perusahaan (David, 2009). Indofood dalam strategi umbrella brand memiliki total skor dari faktor internal kekuatan sebesar 2,2312 dan total skor dari faktor internal kelemahan yaitu 1,0024. Hasil selisih total skor kekuatan dan kelemahan adalah 1,228 yang merupakan koordinat $\mathrm{X}$, sedangkan koordinat $\mathrm{Y}$ ditentukan dari total skor faktor eksternal peluang Indofood dalam strategi umbrella brand yaitu 1,5704 yang dikurangi dengan total skor faktor eksernal ancaman yaitu 1,0576 yang hasilnya adalah 0,5128

\section{Matriks QSPM}

Alternatif strategi 1 adalah Mengembangkan Citra Merek agar merek dapat selalu diingat oleh konsumen. Alternatif strategi ini mendapat TAS (Total Attractiveness Score) 
sebesar 3,456 yang merupakan nilai terendah daripada alternatif strategi lainnya. Strategi ini masih harus dikembangkan oleh Indofood. TAS ini diperolah dari perkalian antara

bobot faktor internal dan eksternal dengan AS (Attractiveness Score). Seiring berjalanya waktu pemikiran manusia mengenai citra merek (brand image) berkembang semakin pesat dan jauh, mereka selalu meinginkan produk terbaik yang populer salah satunya untuk memiliki tampilan mata yang indah dalam waktu singkat dan mudah untuk diingat. Pilihan Product indofood yang telah dikenal dan memiliki citra merek tersendiri yaitu sebagai food solution sudah ada dibenak konsumen sendiri namun dalam perkembangan zaman yang terus berubah membuat indofood berusaha mengembangkan citra mereknya sesuai dengan perkembangan dan perubahan yang diharapkan dan dibutuhkan konsumen.

Alternatif strategi 2 adalah Aktif dalam internet demi memperkuat daya beli konsumen dan selalu ingat terhadap produk atau merek produk Indofood. Alternatif ini mendapatkan nilai TAS sebesar 3,518. Nilai ini merupakan nilai tengah, dan masih berkesinambungan dengan alternatif strategi 1 . Dimana jika pihak Indofood aktif melakukan berbagai promo entah itu mengenai produk baru atau hanya sekedar memberikan info mengenai kegaiatan atau event dari indofood yang akan diselenggarakan atau mengenai pengetahuan produkproduk indofood / info lengkap tentang bahan makanan/ pelengkap makanan yang ada melalui sosial media yang mudah diakses oleh semua kalangan, itu juga akan membantu meningkatkan citra merek produk dan hal itu bisa membuat semakin banyak masyarakat yang tertarik untuk menggunakan atau mengkonsumsi produk indofood sebagai food solution.

Alternatif strategi 3 adalah melakukan inovasi baik pada kemasan, produk ataupun promosi/penawaran-penawaran agar selera konsumen terpenuhi. Alternatif strategi ini mendapat kan nilai TAS 3,742. Nilai ini merupakan nilai tertinggi diantara alternatif strategi lainnya. Dalam hal ini Indofood dapat mempertahankan posisinya sebagai pemimpin pasar jika dapat terus menghasilkan produk-produk inovatif yang diinginkan dan dibutuhkan oleh konsumen.

\section{PENUTUP}

Dari hasil analisis data yang telah diuraikan, maka dapat ditarik kesimpulan sebagai berikut :

1. Dilihat dari faktor internal, kekuatan utama yang dimiliki oleh Indofood adalah dipandang sebagai brand yang memiliki strategi yang cukup matang termasuk dalam strategi Umbrella Brand dan unggul dalam bersaing dikarenakan indofood mampu mempunyai banyak lini produk dengan berbagai inovasi dan strategi didalamnya yang memiliki janji individual masing-masing dalam setiap produknya. Kelemahan utama yang terdapat pada produk Indofood adalah Umbrella Brand (Memayungi banyak produk) yang menciptakan dampak kebingungan persepsi konsumen akan banyaknya produk karena Indofood tidak melakukan promosi secara merata terhadap produknya sehingga membuat konsumen bingung dan tidak menyadari bahwa produk dari indofood. Dilihat dari faktor Eksternal, peluang utama yang dapat dihadapi oleh umbrella brand pada PT Indofood sebagai keunggulan bersaing adalah Hubungan dengan stakeholders (masyakaratsekitar,pedagang/toko eceran).Ancaman utama yang dihadapi umbrella brand sebagai keunggulan bersaing pada PT indofood adalah Beberapa Produk/ jenis produk memiliki kesamaan dengan pesaing yaitu seperti contohnya untuk mie instan, kecap, saos dan lain sebagainya yang memiliki kesamaan dengan pesaing Indofood.

2. Berdasarkan hasil analisis matriks SWOT didapatkan sepuluh alternatif strategi untuk Umbrella brand pada indofood, yaitu :

a. Mempertahankan Pasar yang telah ada dan mengembangkan pangsa pasar

b. Meningkatkan Strategi Brand dengan berbagai cara termasuk promosi.

c. Mengembangkan citra merek agar merek dapat selalu diingat oleh konsumen

d. Dengan adanya daya beli masyarakat, maka lebih mempermudah pendistribusian produk. 


\begin{abstract}
Umbrella Brand e. Meningkatkan diversifikasi produk-produk baru
Strategy

f. Aktif dalam internet demi memperkuat daya beli konsumen dan selalu ingat terhadap produk atau merek

g. Melakukan promosi yang seimbang terhadap produk-produk yang ada.

h. Memiliki Citra Merek yang baik untuk menghadapi pesaing

i. Meningkatkan inovasi-inovasi terbaru untuk produk demi meningkatkan citra merek dan bersaing dengan pesaing

$\begin{array}{lll}312 & \text { j. } & \text { Mencari tahu informasi pergerakan pesaing baik pemasaran,periklanan } \\ \text { k. Strategi yang diterapkan dalam pengembangan strategi umbrella brand }\end{array}$ PT.Indofood sebagai keunggulan bersaing adalah menggunakan strategi bersaing generik untuk strategi Diferensiasi (Differentiation Strategy), dimana perusahaan Indofood melakukan tindakan integratif yang dirancang untuk memproduksi dan menawarkan produk yang dianggap oleh konsumen berbeda dalam hal-hal penting atau unik bagi mereka atau secara inovatif sehingga banyak menciptakan produk yang berbeda dengan pesaing.
\end{abstract}

\title{
DAFTAR PUSTAKA
}

David, Fred R. 2016.Manajemen Strategik Edisi 15. Salemba empat. Jakarta

Keller, Kevin L.2017. Strategic Brand Management. Prentice-Hall,Inc, New Jersey

Kotler, Philip dan Gary Armstrong. 2012. Prinsip-Prinsip Pemasaran. Edisi 12.

Jilid 1. Penerbit Erlangga. Jakarta.

Kotler, Philip dan Gary Amstrong.2004.Dasar-dasar pemasaran edisi kesembilan.Jilid 1. PT Indeks, Jakarta

Kotler,Philip dan Gary Amstrong.1997. Dasar-dasar pemasaran.Jilid 1 . Prehnhallindo, Jakarta

Porter, Michael E.2008. Competitive Advantage: Creating and SustaininghSuperiorPerformance (Terjemahan).Karisma publishing Group, Jakarta

Sumarwan, Ujang, Agus Djunaidi, Aviliani, Royke Singgih, Jusup Agus S, Rico dan Sofyan .2009. Pemasaran Strategik: Strategi Untuk Pertumbuhan Perusahaan dalam Penciptaan Nilai bagi Pemegang Saham. Inti Prima, Jakarta.

Tjiptono, Fandy. 2011. Manajemen \& Strategi Merek. Andi, Yogyakarta

Tjiptono,Fandy. 2008. Strategi Pemasaran . Andi, Yogyakarta.

Tjiptono, Fandy. 2006. Manajemen Jasa. Andi, Yogyakarta

Chandra Dwi Narita. 2012. Analisis Brand Image Handphone Nokia pada mahasiswa IPB. Institut Pertanian Bogor

Dhanovan, Muhammad Derry. 2016. Analisis Strategi Bersaing Mobil. Sazuki Studi Kasus PT Persada Lampung Raya. Universitas Lampung

Loekito Irene. 2014. Analisis Strategi Pemimpin Pasar dan Penantang Pasar berkaitan dengan Keunggulan Bersaing. Sekolah Tinggi Ilmu Ekonomi Kesatuan Bogor.

Lubis,.2010. AnalisisStrategi Brand Extension Kecap ABC ke saus ABC Terhadap Sensivitas Respon Konsumen Pengunjung Carefour Plaza Medan Fair. Universitas Sumatra Utara

Nawingsih.2003. Analisi Ekuitas Merek Warung Laksana Sunda. Institut Pertanian Bogor

Purba, Juni Ronald. 2011. Pengaruh Keunggulan bersaing dalam perumusan strategi pemasaran terhadap citra merek pada rumah makan Wong Solo. Universitas Sumatra Utara

Ratna Sofia. 2014. Analisis Brand Equity Produk Olahan Durian Pada Gerai Sop Duren Lodaya, Bogor. Institut Pertanian Bogor

Safitri Ayu.2017. Analisis Strategi Brand Extension Guna Menciptakan Keunggulan Bersaing. Sekolah Tinggi Ilmu Ekonomi Kesatuan Bogor.

Septianto, Wahyu Tri. 2013. Analisis Strategi Pengembagan Usaha Lapis Bogor Sangkuriang. Insitusi Pertanian Bogor 